Article

\title{
Seasonal Emergence and Historical Contaminant Exposure of Cave Myotis (Myotis velifer) in Central Texas and Current Status of the Population
}

\author{
Tarisha A. Land ${ }^{1, \dagger}$, Donald R. Clark Jr. ${ }^{1, \ddagger}$, Charles E. Pekins ${ }^{2}$ and Thomas E. Lacher Jr. ${ }^{1, *(1)}$ \\ 1 Department of Wildlife and Fisheries Sciences, Texas A\&M University, College Station, TX 77843-2258, USA; \\ tashiland@gmail.com (T.A.L.); drclarkjr@earthlink.net (D.R.C.J.) \\ 2 Environmental Division, United States Army Garrison-Fort Hood, Fort Hood Natural Resources \\ Management Branch, 4622 Engineer Drive, Fort Hood, TX 76544, USA; charles.e.pekins.civ@mail.mil \\ * Correspondence: tlacher@tamu.edu; Tel.: +1-979-255-6131 \\ + Current Address: 5142 Blue Ivy, Bulverde, TX 78163, USA. \\ $\ddagger$ Current Address: 28639 Pleasant Grove Road, North Zulch, TX 77872, USA.
}

Received: 4 October 2019; Accepted: 15 November 2019; Published: 20 November 2019

\begin{abstract}
We examined the emergence patterns of Myotis velifer in central Texas in 2000 and assessed exposure to pesticide residues. We collected and analyzed guano from three caves for pesticide residues. In addition, bat carcasses were sampled from an active colony of cave myotis (Myotis velifer) in Shell Mountain. Organochlorine residue concentrations were highest in guano from the Egypt and Tippit Caves, whereas organophosphate concentrations were highest in Shell Mountain guano. Residue concentrations of organochlorines and metals in guano and carcasses collected from the three caves are considered low and probably of no biological concern. The study was one of very few to demonstrate the presence of OPs, including 18 different detectable compounds in the two most recent samples of bat guano. Comparisons between spring and fall guano samples from Shell Mountain suggest that HCB (hexachlorobenzene), total chlordanes, dieldrin, endrin, endosulfan II, p,p'-DDE (Dichloro-2,2-bis(p-chlorophenyl) ethylene), and o, $\mathrm{p}^{\prime}$-DDT (Dichlorodiphenyltrichloroethane) accumulated while bats were absent from the caves at Fort Hood. Lindane appeared to be the only chemical that increased while the bats were present at the site. Organochlorine concentrations in carcasses were generally lowest in lactating females and higher in nursing juveniles. The pattern of emergence coincides with the peak of agricultural activities, therefore, bats forage at a time when the insect pests are most abundant, but also potential to exposure to agricultural chemicals is highest. The current status of the population, however, remains stable in spite of the history of exposure.
\end{abstract}

Keywords: emergence; Myotis velifer; caves; pesticides; toxicology; ecosystem services

\section{Introduction}

Conservationists and ecologists have begun to examine more closely the role of biodiversity in providing valuable services to humans, both at a global scale [1] and the local scale [2]. Some key benefits include those provided by bats, often overlooked in studies of ecosystem services [3]. Impacts on bats carry a disproportionate economic effect when the magnitude of the ecosystem services they provide is accounted for. Kunz et al. [4] and Jones et al. [5] give estimates of the value that bats provide through pollination, seed dispersal, and consumption of agricultural pests; the value provided to cotton production in south-central Texas alone is estimated at $\$ 741,000 \mathrm{US} /$ year and could range as high as $\$ 1,725,000$ [6]. Hundreds of tropical plants also depend upon bats for pollination services [4]. Benefits go beyond agriculture; the Annual Austin Bat Fest, which draws visitors to watch the emergence of 
bats from the Congress Street Bridge in downtown Austin, brings in an estimated $\$ 3$ million US per year. The role of bats in agriculture and ecotourism has generated new interest in their conservation [5] and emphasized the importance of monitoring the health and viability of colonies [7].

The activity of bats over agricultural areas, however, brings risks. Organophosphorus and carbamate pesticides are used to control a great variety of insects and other invertebrates as well as fungi, birds, mammals, and herbaceous plants [8]. Thousands of chemical products using over 100 different organophosphorus and carbamate compounds registered in the U.S. are applied each year to agricultural crops, forests, rangelands, wetlands, towns, and cities [9]. Bats may be exposed to these anticholinesterase pesticides through the insects they consume [10] or by direct contact when sprays are used while bats are in flight. These compounds are quickly metabolized and excreted by most animals [11,12]. However, sub-acute exposures to anticholinesterases are known to affect an array of behaviors in birds and mammals, such as activity level, alertness, aggression, foraging and drinking, learning and memory, navigation, and reproduction $[8,10,13,14]$.

Organochlorine pesticides such as DDT (Dichlorodiphenyltrichloroethane) also bioaccumulate in food chains. There are considerable data relating to the toxicity and persistence of DDT and its metabolite DDE (1,1-Dichloro-2,2-bis(p-chlorophenyl) ethylene), as well as evidence that the accumulation of these residues increases mortality, lowers reproductive success, and has led to a decline in certain populations of wildlife $[15,16]$. In Missouri, two other organochlorine pesticides, dieldrin (primarily) and heptachlor (secondarily), are thought to have caused the extirpation of an entire colony of gray bats (Myotis grisescens) and increased mortality in three additional colonies [17,18].

Bats contribute greatly to the control of a variety of agriculture pests, especially in central Texas [6]. Large colonies of bats should, therefore, be given special conservation consideration. One common cave-dwelling bat in the lower south-central US is Myotis velifer. This species is a cave specialist and generally occurs in colonies of from 2000-40,000 individuals, and they are permanent residents in the southern part of their range [19-21]. The purpose of this study was to examine summer emergence patterns of a large colony of Myotis velifer on Ft. Hood military base, to assess levels of contaminants in the guano of caves currently and formerly occupied by bats on Ft. Hood, and to examine levels of contaminants in the carcasses of bats collected at this active colony.

\section{Materials and Methods}

\subsection{Cave Descriptions}

The Egypt Cave, located in training area 84, Fort Hood, Coryell County, Texas, was previously inhabited by bats of an undetermined species. The cave was $123.7 \mathrm{~m}$ long at its greatest extent and $4.6 \mathrm{~m}$ in the greatest floor-to-ceiling height [22]. Vegetation around the cave entrance was cleared on 18 May 1998, when this study began. At that time, there was a deposit of guano about $7 \mathrm{~cm}$ thick extending from approximately $3 \mathrm{~m}$ inside the cave to approximately $6 \mathrm{~m}$ inside. There was no evidence of recent usage by bats.

Tippit Cave, located in the training area 85 on Fort Hood, was also previously inhabited by bats of an undetermined species. The cave was $82.3 \mathrm{~m}$ long from the entrance to its deepest point and $16.5 \mathrm{~m}$ in the greatest floor-to-ceiling height [22]. Vegetation around the cave entrance was cleared on 25 May 1998. The cave floor beginning approximately $25 \mathrm{~m}$ from the entrance was covered with a layer of guano approximately $75 \mathrm{~cm}$ thick. There was no evidence of recent usage by bats.

Shell Mountain Bat Cave, located in training area 53, has been historically occupied by bats (heretofore unidentified) and was occupied by a nursery colony of cave myotis (Myotis velifer) at the time of the study. The cave was $116.4 \mathrm{~m}$ from the entrance to its deepest point and $11.1 \mathrm{~m}$ in the greatest floor-to-ceiling height; the main chamber was irregularly shaped and approximately $26 \mathrm{~m}$ long. A tent-shaped steel bat gate had previously been installed at the main entrance, and a steel grid gate was present at the small entrance [22]; censusing and monitoring of the bats was recommended by the nature conservancy [23]. Fort Hood has managed and monitored the colony since 2003 (Charles 
E. Pekins, Wildlife Biologist, Fort Hood Natural Resources Branch), and both exits were replaced with bat-friendly cupolas. There was a large room directly under the tent-shaped gate where the bats would roost, and guano covered the floor to a depth of approximately $1 \mathrm{~m}$. The cave was continued to be monitored post-study up until the present day.

\subsection{Colony Size and Emergence Patterns}

Exit counts were conducted at Shell Mountain Bat cave one night each month for 13 consecutive months, July 1999 through July 2000. Numbers were derived by recording emergences on a Sony digital video camera recorder (DCRTRV10). The camera was mounted, secured on a tripod, and placed approximately $10 \mathrm{~m}$ east of the cave entrance. The cave opening was completely captured within the frame of the camera. The zero lux tool on the camcorder was used in an effort to minimize the disturbance to the bats. The night vision was turned on as the available light became less; this technique was used in an attempt to retain as natural an atmosphere as possible and not alter the normal emergence patterns. The recorded emergences were viewed after the recording had been made. Each tape was reviewed, and every individual on the screen was counted for one second of each minute for the duration of the emergence. Previous research [24,25] used this technique to estimate the colony size at over 16,000 individuals, but emergence patterns over the 13-month period were not previously published. Since 2004, using the same technique, Fort Hood has collected microclimate data and conducted emergence counts during March-October.

\subsection{Guano Samples}

Guano samples were collected from the surface of guano piles in caves to reflect the most recently deposited guano in the chamber using aluminum foil to scoop a sample from the guano surface. Samples were wrapped in foil and placed in self-sealing plastic freezer bags and stored in an ice chest with dry ice until placement in an ultracold freezer $\left(-80^{\circ} \mathrm{C}\right)$ at Texas A\&M University; samples were analyzed in 1999 and 2000. Collection in this manner has been applied in many studies and, short of collecting the guano as it falls, is the only practical method. We attempted to collect guano with minimal degradation of the fecal pellets, and all extraneous materials were removed prior to analysis.

The single guano sample collected from Egypt Cave on 12 April 1999 (Sample 1) was divided into 4 subsamples (one for each type of analysis), ranging from approximately 60 to $70 \mathrm{~g}$ each. The guano sample collected from Tippit Cave on 12 April 1999 (Sample 2) was also divided into 4 subsamples, which ranged from about 65 to $75 \mathrm{~g}$ each. Guano samples were also collected from Shell Mountain Bat Cave on 16 September 1998 (sample 3), 13 March 1999 (Sample 4), 23 September 1999 (Sample 5), and 14 May 2000 (Sample 6). Overall the subsamples from Shell Mountain ranged from about 12 to $77 \mathrm{~g}$.

Guano samples were collected early and late in the activity season of bats to judge whether residues increased or decreased while the bats were present and feeding in the vicinity of Fort Hood. If a residue increased from spring to fall and decreased from fall to spring, it was assumed that this chemical accumulated mostly while the bats were at Shell Mountain. Conversely, if the residue decreased from spring to fall and increased from fall to spring, the chemical was believed to be acquired while the bats roosted at locations other than at Shell Mountain.

\subsection{Bat Samples}

Seven bat carcasses (Sample numbers 7-13) were analyzed for organochlorines. Bats were taken under the authority of the Texas Parks and Wildlife Division Scientific Collecting Permit SPR-1098-973 issued to T. E. Lacher, Jr. following the guidelines of the American Society of Mammologists for collection and handling [26]. As bats exited the gate, they were captured using a hand net. Each bat was removed from the net, sex and age (juvenile or adult) determined, and retained if desired. Only one female (Sample 9) was pregnant. Bats were placed in cloth bags, then placed into a container with dry ice. Newspapers were used to insulate the bats, thus they were not in direct contact with the ice. Carbon dioxide caused death by asphyxiation within $2 \mathrm{~min}$. After the bats were euthanized, they were 
wrapped in aluminum foil and placed individually in small plastic bags. These were then placed in an ice chest with dry ice and transported to Texas A\&M University, where they were stored in an ultracold freezer at $-80{ }^{\circ} \mathrm{C}$.

After the bats were thawed, the skin, feet, wings, gastrointestinal tract, and head were removed; the remaining carcasses were weighed (Table 1). Each carcass was placed in a chemically cleaned glass jar, sealed with paraffin tape, and transported to the Geochemical and Environmental Research Group (GERG) of Texas A\&M University, College Station, for chemical analysis.

Table 1. Shell Mountain bat cave bat carcasses.

\begin{tabular}{cccccc}
\hline Date & Sample Number & Carcass Weight & Age & Sex & Reproduction \\
\hline $09 / 23 / 99$ & 11 & $5.82 \mathrm{~g}$ & adult & male & - \\
$09 / 23 / 99$ & 13 & $4.68 \mathrm{~g}$ & adult & female & - \\
$03 / 13 / 00$ & 12 & $5.93 \mathrm{~g}$ & adult & female & - \\
$05 / 14 / 00$ & 07 & $0.92 \mathrm{~g}$ & fetal & female & - \\
$05 / 14 / 00$ & 08 & $2.92 \mathrm{~g}$ & juvenile & female & - \\
$05 / 14 / 00$ & 09 & $6.21 \mathrm{~g}$ & adult & female & lactating \\
$05 / 14 / 00$ & 10 & $3.81 \mathrm{~g}$ & juvenile & male & - \\
\hline
\end{tabular}

\subsection{Chemical Analyses}

Guano samples were collected from Egypt, Tippit, and Shell Mountain caves and analyzed for organochlorines, organophosphates, carbamates, pyrethroids, and heavy metals by GERG in 1999-2000. The analyses followed GERG's standard analytical procedures for organochlorines [27], carbamates [28], and pyrethroids [29].

Samples of guano integrate residues from $100 \mathrm{~s}$ to $1000 \mathrm{~s}$ of individual bats over a period of time; even though a single sample of guano was analyzed, it was more reliable than the analysis of a single bat or even of several bats [30]. To simplify and focus on the potentially more important residues, the only chlorinated benzene discussed was HCB and the only hexachlorochyclohexane was lindane; all chlordane-related chemicals have been summed to obtain a single value; and among the DDT group, only $\mathrm{p}, \mathrm{p}^{\prime}$-DDE and $\mathrm{o}, \mathrm{p}^{\prime}$-DDT are considered in this paper. These were selected because $p, p^{\prime}$-DDE was the primary chemical involved and o, $p^{\prime}$-DDT if found, would indicate recent usage of DDT in the field. For organic pollutant analyses (organochlorine pesticides, PCBs, (polychlorinated biphenyls) organophosphates, carbamates, and pyrethroids), guano and carcass tissue samples were extracted 3 times with methylene chloride. Samples were first mixed with anhydrous sodium sulfate before macerating with methylene chloride. Sample extracts were purified with silica gel/alumina column chromatography followed by gel permeation liquid chromatography for analysis of organochlorine pesticides, PCBs and pyrethroids. Organochlorine pesticides and PCBs were analyzed with a Hewlett-Packard (HP) 5890 gas chromatograph equipped with electron capture detector (GC/ECD) using a $30 \mathrm{~m} \times 0.25 \mathrm{~mm}$ i.d. DB-5 (J\&W Science) fused silica capillary column. Organophosphates and pyrethroids were analyzed with an HP 6890/5973 gas chromatography/mass spectrometry (GC/MS) using $30 \mathrm{~m} \times 0.25 \mathrm{~mm}$ i.d. DB- $5 \mathrm{~ms}$ fused silica capillary column (J\&W Science) under selective ion mode (SIM).

The identification of compounds was based on retention time for organochlorine pesticides and PCBs, and retention times and selective ions for organophosphates and pyrethroids. The GC/MS was calibrated with known concentrations of analytes at 5 different concentrations, and the average response factors of the analytes were used for analyte concentration determination. The GC/ECD was calibrated with known concentrations of analytes at 5 different concentrations. Target compounds were quantified using internal standard techniques. Quantitation of compounds was based on the response factors determined from calibrations and surrogate compounds added prior to extraction.

Samples for carbamate analysis were extracted with methylene chloride/acetone $(1: 1, \mathrm{v} / \mathrm{v})$. Sample extracts were concentrated and extracted into acetonitrile after adding methylene chloride. Acetonitrile extracts were concentrated by a rotary evaporator and analyzed by high-performance 
liquid chromatography (HPLC) with a fluorescence detector using instrument settings and wavelengths based on reference [28].

For mercury, samples were digested with sulfuric acid and nitric acid and analyzed using cold vapor atomic absorption spectrometry. Samples were digested with nitric acid for other inorganic elemental analysis. Arsenic, cadmium, lead, and selenium were analyzed by graphite furnace atomic absorption technique, and other elements were analyzed by inductively coupled plasma spectrometry.

The method detection limits (MDLs) for chlorinated pesticides and PCBs were 0.1 to $0.5 \mathrm{ng} / \mathrm{g}$ $(\mathrm{ppb})$ on a dry-weight basis. The MDLs for organophosphates and pyrethroids were $0.5 \mathrm{and} 1 \mathrm{ng} / \mathrm{g}$, respectively. MDLs for the carbamates were $1 \mu \mathrm{g} / \mathrm{g}$ (ppm). MDLs for inorganic elements ranged from 0.1 to $1 \mu \mathrm{g} / \mathrm{g}$ for different elements.

Residue values reported by GERG as $\mathrm{J}=<$ minimum detection level, $\mathrm{I}=$ interference, or $\mathrm{ND}=$ not detected, have not been presented numerically in these analyses, and all of these results are indicated by dots in the tables. Residue data were reported as ppb, except for metals, which were reported as ppm.

\section{Results}

\subsection{Emergence Patterns during Crop Season}

Bats had migrated and were absent from Shell Mountain cave between November and February, but began to return and emerge in small numbers in March (Figure 1b), which then increased rapidly in abundance to a peak emergence in July, in both 1999 and 2000 (Figure 1a,b). The bats typically emerged in pulses, which were most prominent during the months of heaviest emergence. Peak emergence from May through August matched the agricultural growing season in central Texas. The time of the first emergence varied by month, tracking the change in time of sunrise (Figure 2).

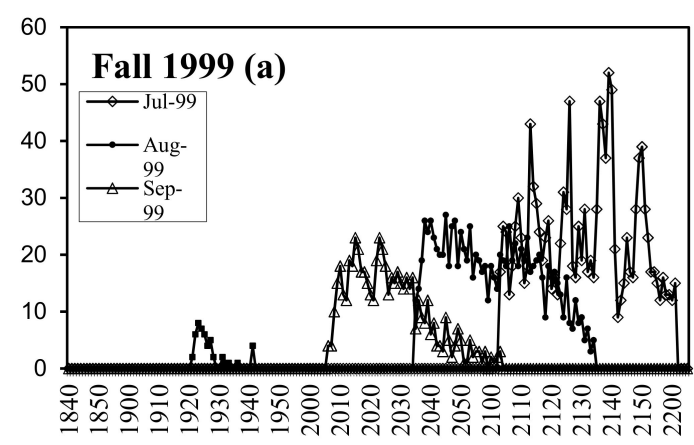

(a)

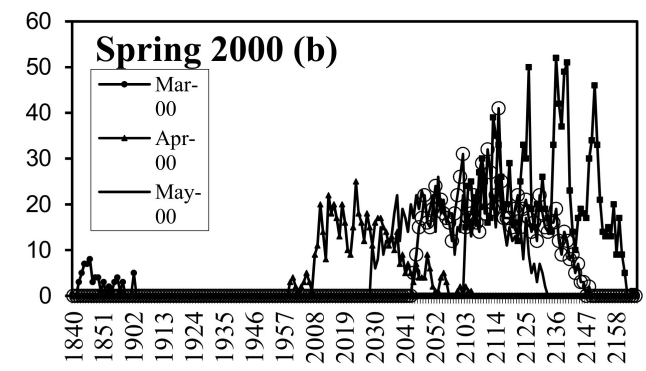

(b)

Figure 1. Emergence patterns in the Fall of 1999 (a) and Spring of 2000 (b) showing the shift in emergence times in response to season and the increase in emergence size throughout the summer. Numbers on the Y-axis are individuals counted in one-second intervals/minute throughout the emergence. Note that July data were collected on both seasons, and the pattern is highly consistent from year to year. 


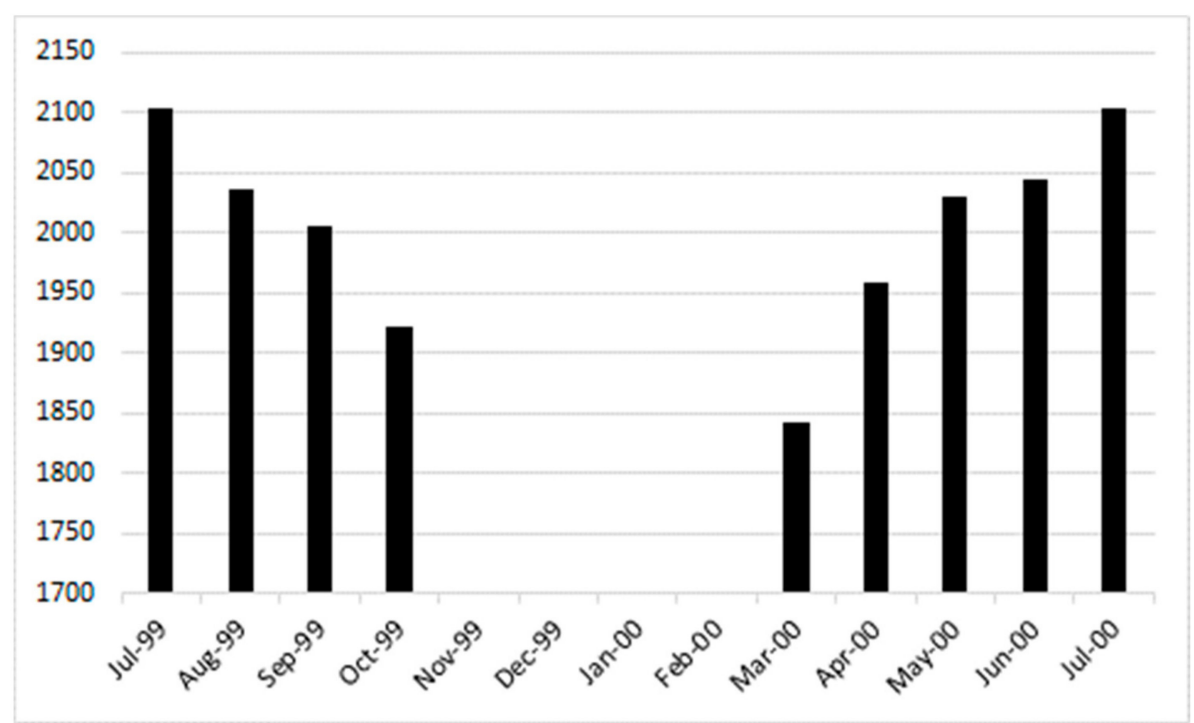

Figure 2. Time of emergence by month, which closely follows the time of dusk, about ten minutes after the reported time of sunset. Times on Y-axis are in Central Standard Time. There was no emergence between November and February, inclusive.

\subsection{Organochlorines in Guano}

Lindane was the only chemical that appeared to increase while bats roosted at Shell Mountain. $\mathrm{HCB}$, total chlordanes, dieldrin, endrin, endosulfan II, p, $\mathrm{p}^{\prime}$-DDE, and o, $\mathrm{p}^{\prime}$-DDT all showed the opposite pattern, which suggested that bats accumulated those compounds elsewhere, and they declined while bats were at Shell Mountain. Egypt and Tippit Caves showed the highest accumulations of total chlordanes, endrin, dieldrin, mirex, p, $\mathrm{p}^{\prime}$-DDE, and o, $\mathrm{p}^{\prime}$-DDT (Table 2).

Table 2. Organochlorines (ppb) in guano from Shell Mountain (SM), Egypt, and Tippit Caves. Only Shell Mountain had an active bat colony and was sampled in four different seasons. $\mathrm{F}=$ Fall and $\mathrm{S}=$ Spring. Dots represent non-reported numerical values that were either below minimum detection level, subject to interference, or not detected.

\begin{tabular}{ccccccc}
\hline Compound & $\begin{array}{c}\text { Sample 1 } \\
\text { Egypt }\end{array}$ & $\begin{array}{c}\text { Sample 2 } \\
\text { Tippit }\end{array}$ & $\begin{array}{c}\text { Sample 3 } \\
\text { SM (F1998) }\end{array}$ & $\begin{array}{c}\text { Sample 4 } \\
\text { SM (S1999) }\end{array}$ & $\begin{array}{c}\text { Sample 5 } \\
\text { SM (F1999) }\end{array}$ & $\begin{array}{c}\text { Sample 6 } \\
\text { SM (S2000) }\end{array}$ \\
\hline Total PCB & 94.7 & 91.2 & 52.2 & 48.7 & 40.4 & 1114 \\
HCB & 2.49 & 2 & 40.2 & 44.9 & 38.6 & 66.1 \\
Lindane & 1.55 & 0.81 & 0.71 & 0.42 & 2.38 & 0.81 \\
Total & 193 & 163 & 91 & 121 & 25.4 & 95.6 \\
Chlordanes & & & & & 4.7 & 15.3 \\
Dieldrin & 98.5 & 84.6 & 27.6 & 4.2 & $\bullet$ & 1.85 \\
Endrin & 6.87 & 2.95 & $\bullet$ & 1.48 & $\bullet$ & 0.89 \\
Mirex & 11 & 8.84 & 3.06 & 2.79 & $\bullet$ & 8.7 \\
Endosulfan II & 9.93 & 8.04 & 3.58 & 4.27 & $\bullet$ & 92.4 \\
p,p'-DDE & 240 & 186 & 63.1 & 63.3 & 24.5 & 1.29 \\
o,p'-DDT & 7.93 & 6.03 & 3.58 & 4.69 & $\bullet$ & \\
\hline
\end{tabular}

\subsection{Organophosphates in Guano}

OP levels from Egypt and Tippit Caves were either below detection levels or present in very low concentrations (Table 3). There were 18 different OPs detected in Shell Mountain cave, however, in particular in the two most recent sample periods. Terbufos was the only organophosphate chemical to show a consistent pattern that would suggest where it originated seasonally. It increased from fall to spring and decreased from spring to fall, indicating accumulation off the Fort. The highest concentrations of these anticholinesterase chemicals were found at Shell Mountain Cave, except for 
diazinon, which showed higher levels at the two abandoned caves. The two recent samples from Shell Mountain showed large increases in tokuthion, carbophenothion, disulfoton, and EPN (O-Ethyl O-(4-nitrophenyl) phenylphosphonothioate )(Table 3).

Table 3. Organophosphates ( $\mathrm{ppb}$ ) in guano from Shell Mountain, Egypt, and Tippit Caves. Dots represent non-reported numerical values that were either below minimum detection level, subject to interference, or not detected.

\begin{tabular}{ccccccc}
\hline Compound & $\begin{array}{c}\text { Sample 1 } \\
\text { Egypt }\end{array}$ & $\begin{array}{c}\text { Sample 2 } \\
\text { Tippit }\end{array}$ & $\begin{array}{c}\text { Sample 3 } \\
\text { SM (F1998) }\end{array}$ & $\begin{array}{c}\text { Sample 4 } \\
\text { SM (S1999) }\end{array}$ & $\begin{array}{c}\text { Sample 5 } \\
\text { SM (F1999) }\end{array}$ & $\begin{array}{c}\text { Sample 6 } \\
\text { SM (S2000) }\end{array}$ \\
\hline Dichlorvos & $\bullet$ & $\bullet$ & $\bullet$ & 0.7 & 1.7 & 5 \\
Naled & 0.7 & $\bullet$ & $\bullet$ & 2.9 & 9.4 & 8.3 \\
Monochrotophos & $\bullet$ & $\bullet$ & $\bullet$ & $\bullet$ & 0.6 & 2.4 \\
Demetron-S & 1.5 & 0.6 & 7.4 & 2.4 & 12 & 14 \\
Dimethoate & $\bullet$ & $\bullet$ & $\bullet$ & $\bullet$ & 20.2 & 0.5 \\
Terbufos & 5 & 1.9 & 2 & 33.7 & 25.7 & 36 \\
Diazinon & 4.2 & 0.7 & $\bullet$ & 1.1 & 2 & 1.1 \\
EPN & 0.6 & $\bullet$ & 0.5 & 0.5 & 8 & 2.8 \\
Disulfoton & 2.2 & 0.5 & 1.3 & 2.5 & 13.5 & 13.9 \\
M parathion & 1.3 & $\bullet$ & 0.7 & 3.3 & 16.6 & 5.9 \\
Parathion & $\bullet$ & $\bullet$ & $\bullet$ & $\bullet$ & 1.3 & $\bullet$ \\
Trichloronate & $\bullet$ & $\bullet$ & $\bullet$ & $\bullet$ & $\bullet$ & 0.8 \\
Stiriphos & 1.6 & $\bullet$ & $\bullet$ & $\bullet$ & 2.4 & 2.2 \\
DEF (merphos) & 11.2 & 9.8 & 2.1 & 10.8 & 0.9 & 2.3 \\
Fensulfothion & $\bullet$ & $\bullet$ & $\bullet$ & $\bullet$ & 170 & 200 \\
Carbophenothion & 1.1 & $\bullet$ & 0.5 & 0.6 & 481 & 138 \\
Tokuthion & 0.8 & $\bullet$ & 1.7 & 18.4 & $\bullet$ & 2.9 \\
Methylazinphos & 0.9 & 1.2 & $\bullet$ & 1.7 & & $\bullet$ \\
\hline
\end{tabular}

\subsection{Metals in Guano}

The seasonal patterns of accumulation for cadmium, lead, and zinc indicated that these metals were acquired while the bats were away from Shell Mountain Cave (Table 4). No metals showed the opposite trend. Given that guano was taken only from the most freshly deposited layer, it would not be influenced in any way by metals in the cave. Guano from Egypt and Tippit Caves had the highest amounts of arsenic, nickel, and mercury. The highest concentrations of the other five metals were found at Shell Mountain Cave (Table 4), with one outlier level for lead in Sample 6.

Table 4. Metals (ppm, $\mu \mathrm{g} / \mathrm{g}$ dry weight) in guano from Shell Mountain, Egypt, and Tippit Caves.

\begin{tabular}{ccccccc}
\hline Compound & $\begin{array}{c}\text { Sample 1 } \\
\text { Egypt }\end{array}$ & $\begin{array}{c}\text { Sample 2 } \\
\text { Tippit }\end{array}$ & $\begin{array}{c}\text { Sample 3 } \\
\text { SM (F1998) }\end{array}$ & $\begin{array}{c}\text { Sample 4 } \\
\text { SM (S1999) }\end{array}$ & $\begin{array}{c}\text { Sample 5 } \\
\text { SM (F1999) }\end{array}$ & $\begin{array}{c}\text { Sample 6 } \\
\text { SM (S2000) }\end{array}$ \\
\hline Arsenic & 7.17 & 8.64 & 6.87 & 7.31 & 6.17 & 2.54 \\
Cadmium & 1.07 & 1.21 & 1.0 & 1.13 & 0.83 & 1.7 \\
Lead & 4.33 & 4.47 & 4.14 & 4.53 & 3.26 & 75.6 \\
Chromium & 1.28 & 1.27 & 1.09 & 0.97 & 0.99 & 1.82 \\
Nickel & 2.45 & 2.93 & 1.96 & 2.07 & 1.94 & 1.26 \\
Mercury & 0.41 & 0.21 & 0.22 & 0.21 & 0.19 & 0.19 \\
\hline
\end{tabular}

\subsection{Organochlorines in Carcasses}

Only the OCs in carcasses were measured; these were the obvious choice for analysis due to the likelihood of their presence and because more was known about the possible effects of these compounds when measured in tissues. Only five organochlorine residues, or residue groups, were quantifiable in the bat carcasses. These were total PCBs, HCB, total chlordanes, dieldrin, and p, p'-DDE. The two adult females (One lactating) had the smallest amount of total PCBs, of the compounds that were analyzed (Table 5). These residues tended to be highest in the juvenile (i.e., nursing) bats. 
Table 5. Organochlorines (ppb, ng/g wet weight) in bat carcasses from Shell Mountain Bat Cave. Dots represent non-reported numerical values that were either below minimum detection level, subject to interference, or not detected.

\begin{tabular}{|c|c|c|c|c|c|c|c|}
\hline Compound & $\begin{array}{c}\text { Sample } 7 \\
\text { Female-Fetal }\end{array}$ & $\begin{array}{c}\text { Sample } 8 \\
\text { Female Juvenile }\end{array}$ & $\begin{array}{c}\text { Sample } 9 \\
\text { Female Adult } \\
\text { (Lactating) }\end{array}$ & $\begin{array}{c}\text { Sample } 10 \\
\text { Male Juvenile }\end{array}$ & $\begin{array}{c}\text { Sample } 11 \\
\text { Male Adult }\end{array}$ & $\begin{array}{c}\text { Sample } 12 \\
\text { Female Adult }\end{array}$ & $\begin{array}{c}\text { Sample } 13 \\
\text { Female Adult }\end{array}$ \\
\hline Total PCBs & 48.8 & 76.7 & 31.1 & 77.2 & 192 & 38.6 & 28.4 \\
\hline Lindane & $\bullet$ & $\bullet$ & $\bullet$ & 0.428 & $\bullet$ & 0.444 & $\bullet$ \\
\hline $\begin{array}{c}\text { Total } \\
\text { Chlordanes }\end{array}$ & 16.2 & 42.6 & 7.29 & 49.3 & 66.1 & 23.2 & 20.2 \\
\hline Mirex & $\bullet$ & 1.5 & 1.99 & 13.4 & 2.83 & 1.84 & $\bullet$ \\
\hline Endosulfan II & $\bullet$ & 0.8 & $\bullet$ & $\begin{array}{l}1.4 \\
0.747\end{array}$ & $\bullet$ & $\begin{array}{l}1.04 \\
0.395\end{array}$ & - \\
\hline$p, p^{\prime}-D D E$ & 119 & 753 & 99.8 & 294 & 266 & 172 & 106 \\
\hline $0, p^{\prime}-D D T$ & $\bullet$ & 0.867 & $\bullet$ & $\bullet$ & 1.55 & $\bullet$ & $\bullet$ \\
\hline
\end{tabular}

\subsection{Carbamates and Pyrethroids}

Carbamate levels were all either not detected, below MDL, or uncertain due to interference. Pyrethroids were not detected in any samples.

\section{Discussion}

\subsection{Organochlorine Residues}

Lindane was the single organochlorine compound that increased while the bats were at Fort Hood. Lindane was introduced in 1952 [31] and used as a livestock spray on range cattle, but it was stopped an unknown number of years ago (Ann Hamilton, Fort Hood Pest Management and Pest Control, pers. comm.). Organochlorines that appeared to increase while bats roosted away from Shell Mountain Bat Cave were HCB, total chlordanes, dieldrin, endrin, endosulfan II, p, p'-DDE, and o, p'-DDT. We presume residual residues of these compounds were higher in the insect diet encountered by these bats in areas to which they migrated. Organochlorine residues were consistently higher in guano than in bat carcasses, with the exception of $\mathrm{p}, \mathrm{p}^{\prime}$-DDE.

Aldrin was used from the 1950s throughout the early 1970s in the United States as a soil insecticide to control rootworms, beetles, and termites [32]. When applied in the environment, aldrin quickly degrades into dieldrin. Dieldrin concentrations of 0.4 to $1.1 \mathrm{ppm}$ in guano were associated with mortality in gray bat (Myotis grisescens) colonies [30]. Levels detected in bat guano at Shell Mountain were at least an order of magnitude lower, with the highest levels being $40.2 \mathrm{ppb}$.

DDT was used in the United States until 1972. The colony of free-tailed bats (Tadarida brasiliensis) at Carlsbad Cavern, New Mexico, probably declined due to DDT [33]. DDE concentrations in the guano of 3 ppm have been linked to declining colonies of gray bats and Mexican free-tailed bats [34]. O'Shea and Clark [35], in an assessment of the risk of DDT to the endangered Indiana bat, Myotis sodalis, report that the minimum lethal concentration of DDE in brains in the related bat Myotis lucifugus was $540 \mathrm{ppm}$. Mispagel et al. [36] examined residues of DDT, DDD (Dichlorodiphenyldichloroethane), and DDE in southern bent-wing bats (Miniopterus schreibersii) in Australia to assess their possible role in the decline of this species. Wet weight values of DDE in ppb ranged from $114 \mathrm{ppb}$ body burden in males in one of the studied caves to $24.2 \mathrm{ppm}$ in females in back-depot fat in another cave. None of the levels observed appeared to be high enough to contribute to declines, which were likely related to climatic effects and habitat disturbance. Kannan et al. [31] examined a number of persistent organic compounds, including DDT and metabolites in a cave in New York State where little brown bats (Myotis lucifugus) were infected with white-nose syndrome and in a non-infected control cave in Kentucky. DDT levels (reported as p, $\mathrm{p}^{\prime}$-DDT $+\mathrm{p}, \mathrm{p}^{\prime}$-DDD $+\mathrm{p}, \mathrm{p}^{\prime}$-DDE) in ppb wet weight in fat tissues were as high as 5340 in one of the Kentucky samples and 2850 in a NY sample, however, there was no difference in infected and non-infected sites overall and none of the measured persistent organics seemed to be related to the presence of white-nose syndrome. In this study, Egypt Cave showed a maximum DDE concentration 
of $240 \mathrm{ppb}$. None of the present levels of DDT derivatives ( $\left.\mathrm{p}, \mathrm{p}^{\prime}-\mathrm{DDE}, \mathrm{o}, \mathrm{p}^{\prime}-\mathrm{DDT}\right)$ found in the guano at Fort Hood were high enough to be considered harmful.

Guano from the two abandoned caves, Egypt and Tippit, showed greater maximum levels of total chlordanes, endrin, dieldrin, mirex, $\mathrm{p}, \mathrm{p}^{\prime}$-DDE, and o, $\mathrm{p}^{\prime}$-DDT, than did guano from Shell Mountain. This may reflect higher past levels of these organochlorines in the environment.

\subsection{Organophosphate Residues}

Organophosphates are generally more acutely toxic to wildlife than organochlorines [37]. The presence of 18 different compounds in the guano at Shell Mountain were detected. The only organophosphate that showed a consistent seasonal pattern of increase and decrease was terbufos, which was apparently accumulated off Fort Hood, though it could as well be related to early spring application. Terbufos is used as an agricultural pesticide primarily for soil insects and nematodes. Diazinon was highest in guano from Egypt Cave, now abandoned. Diazinon is used to control insects in the soil, on ornamental plants, and on fruit and vegetable crops. Wolfe and Kendall [38] found that passerine birds may be highly sensitive to terbufos and diazinon, but effects on bats are unknown. Agosta [39] summarizes possible impacts on the status of Eptesicus fuscus, including those of pesticides. He highlights the potential for exposure to OPs (organophosphates) and carbamates through the consumption of insects in over-sprayed agricultural fields but mentions the lack of data on residue levels collected under these scenarios.

Organophosphates were in higher levels in the Shell Mountain guano, and this may reflect the increased use of these compounds in recent years. The large number of organophosphates we detected have not been previously recovered from bat guano, though Sandel [40] detected cis-permethrin in the guano of Tadarida brasiliensis in Texas. The effects of these compounds on the colony are unknown. However, these residues do indicate exposure of bats to organophosphates through their diet. The presence of DEF, in particular, suggests that bats were foraging over cotton.

\subsection{Heavy Metal Residues}

Lead is a toxic metal that inhibits the activities of many enzymes necessary for normal biological functions [41]. The highest amount of lead previously reported in bat guano was 65 ppm [42]; one sample from Shell Mountain showed $76 \mathrm{ppm}$. Bats with lead amounts of $65 \mathrm{ppm}$ in their guano showed no adverse effects [42], but whether $76 \mathrm{ppm}$ represents concentrations that approach a threshold of harm to bats is unknown. Some of the metals (arsenic, nickel, and mercury) were found in guano from Egypt and Tippit Caves at minimal levels, which suggests that these metals may have decreased in the environment in recent years.

\subsection{Patterns of Accumulation and Ecological Effects}

Bats appear to have accumulated HCB, total chlordanes, dieldrin, endrin, endosulfan II, p, p'-DDE, o,p'-DDT, terbufos, cadmium, lead, and zinc while they were away from Fort Hood. Lindane appeared to be the only chemical that increased while the bats were present at the site. This may reflect that lindane was used extensively as a livestock spray years ago on Fort Hood and that residual amounts are still present in the local environment. Organochlorines found in bat carcasses were suggestive of accumulation in the nursing juveniles and loss in the lactating female. This has previously been noted in bats [42,43] as well as in marine mammals [44].

The impact of organophosphates, carbamates, persistent organic compounds, and heavy metals on bats remains poorly documented by empirical data collected under field conditions. That said, there are numerous documented cases of significant impacts on local populations that suggest that impacts could be more severe [42]. Data on impacts are regional and scattered, however, Eidels et al. [45] examined the dose-response curves of big brown bats, Eptesicus fuscus, to chlorpyriphos under laboratory conditions. They determined that repeated low-dose exposure could impact long-term survival and reproduction. Recovery of brain and plasma ChE activity after dosing took up to 14 days. The potential 
impact on foraging for adults and especially neonates, could be significant. Bats (Pipistrellus pipistrellus and Myotis myst-nat) foraging over an apple orchard in Germany were exposed to applications of a carbamate (fenoxycarb) and an organophosphate (Chlorpyriphos) [46]. A risk assessment conducted based upon bat activity, and exposure to residues on arthropods suggested these bats were more likely to be sensitive to reproductive effects than to acute dietary impacts. There is almost no data on the impact of agricultural pesticides on bats in the tropics [42], regions with high bat species richness [47]. Oliveira et al. [48] in a controlled exposure experiment exposed the frugivorous bat Artibeus lituratus to the pyrethroid deltamethrin to assess potential dietary exposure. They observed impacts on carbohydrate metabolism, oxidative stress in liver and pectoral muscle, and possible impacts on flight, reproduction, and general metabolism. De Lange et al. [49] attempted to address the lack of field data through the development of a model to assess risk and vulnerability to pesticides based on a comprehensive list of autecological information. In their model, bats were indicated as being particularly vulnerable to both DDT and the OP chlorpyrifos, however, the analysis was restricted to a small number of European species.

None of the organochlorines or metals is thought to threaten the Shell Mountain colony at the concentrations measured. There are no data on which to evaluate the organophosphates; however, the large increases in tokuthion, carbophenothion, disulfoton, and EPN in the most recent samples warrant continued sampling, perhaps annually. No great amount of mortality was observed in the Shell Mountain colony of cave myotis, and the bats appeared to be reproducing successfully. The colony is still productive and is considered a key colony needed for long-term population viability in the region. Cleveland et al. [6] report that 9 of 45 bat species in the United States are endangered, and those that occupy cave ecosystems are most vulnerable. Myotis velifer is listed as Least Concern by the IUCN (http://www.iucnredlist.org/details/14208/0), but this species has been documented as having demanding conditions for hibernacula requiring high humidity and little air movement [20]. They also have a low tolerance for weight loss [20]. It is a former Candidate 2 species for the U.S. Fish and Wildlife Service.

Our estimate for the total population of this colony in 2000 was between 8400 and 16,700 individuals [25]; Ammerman et al. [19] reported colonies up to 40,000 bats and co-author Perkins has continued the census method and recently estimated up to 30,000 bats during June and July when the pups become volant at Shell Mountain and in other north-central Texas caves. The use of digital imagery to estimate emergence patterns has also been successfully applied in the tropics and is applicable whenever there is a narrow emergence opening [50]. No decline in abundance has been observed, however, the colony has begun to switch roosts in June and July for the past 2.5 years. Due to the configuration in the caves at the alternate roosts, the census method cannot be applied, but the population estimates each year at Shell Mountain prior to the switch has remained consistent at the same baseline. In addition, every Spring for the past 20 years, the bats return to Shell Mountain. The pattern of emergence times indicates that bats are most active during the peak of agricultural activity. This would make them effective predators on potential agricultural pests but also expose them to possible pesticide exposure. The Shell Mountain data on organophosphate residues suggest this might be the case. The emergence of cave myotis varies by season, generally occurring 15-20 min after sunset [19,51,52]. Their feeding habits have been described as opportunistic, varying by season, and they feed twice per night, right after sunset and pre-dawn [20]. Kunz [52] states that they forage low, from 2 to $14 \mathrm{~m}$ above ground, which means that they forage much lower than Tadarida brasiliensis in central Texas (documented at 200-1200 m) and likely forage on different prey [6]. Kunz [53] reports that $80 \%$ of prey consumption occurs in the first two hours after emergence, thus minimizing disturbance at this time is critical. Females in Kansas had maximum daily consumption in July and August of $25 \%-30 \%$ of their body weight, and males were slightly lower at $20 \%-25 \%$. During foraging bouts in Kansas Myotis velifer consumed Coleoptera (37.4\%), Homoptera (17.9\%), Diptera (14.4\%), Lepidoptera $(11.6 \%)$, Hemiptera $(9.2 \%)$ and $9.2 \%$ other taxa [53]. This is a very diverse diet compared to high flying moth specialists like Tadarida brasiliensis [6].

Myotis velifer colonies are smaller than those of Tadarida brasiliensis, but their scattered nature and the different foraging heights and strategies mean that these two species likely are complementary in 
the consumption of insects throughout Texas. The population at Shell Mountain is under constant monitoring and appears to be stable to growing. We believe the efforts of Fort Hood to ensure the protection and future of this large colony are important.

\section{Conclusions}

The transition of the planet into a new era, described as the Anthropocene, where multiple threats increase in magnitude and interact in a complex fashion, has raised great concern over the future of biodiversity and the ecosystem services provided [54]. A recent volume focuses on the threats to bats in this era [55], including the threats imposed by the use of agricultural chemicals [56]. Williams-Guillén et al. [56] discussed the role of agricultural pesticides on bats in the Anthropocene. Bats are impacted both by agricultural intensification and the expanded use of agricultural chemicals, however, other than a fairly clear understanding of the impact of organochlorines on bats, the effects of newer generation compounds, such as neonicotinoids and pyrethroids, in wild populations are still poorly understood. There is concern over the chronic effects of low levels of organochlorines on reproduction, immune response, endocrine disruption, and behavior [57]. The recent review by Bayat et al. [57] emphasizes the importance of understanding the neurological and physiological effects of long-term sub-lethal exposure, as there is still a lack of toxicity endpoints for many compounds.

The colony of Myotis velifer in central Texas showed continued exposure to organochlorine and organophosphate pesticides through the examination of residues in guano and in carcasses of bats in 2000. OCs, including several no longer in use, remained present in the environment but likely posed a relatively low hazard to bats. We detected 18 OPs in the guano samples, and several of these would be of concern due to their potential high toxicity and unknown metabolic, reproductive, and population impacts on the bat population. The colony at Shell Mountain has remained stable since the contaminant assessment in 2000, however, continued monitoring of this and other colonies in the region are warranted, as well as a better understanding of the consequences of long-term exposure to low levels of organophosphates.

Author Contributions: Conceptualization, T.A.L., D.R.C.J, and T.E.L.J.; methodology, T.A.L., and D.R.C.J.; formal analysis, T.A.L., C.E.P., and D.R.C.; investigation, T.A.L., D.R.C.J., C.E.P., and T.E.L.J.; resources, D.R.C.J.; writing-Original draft preparation, T.A.L.; writing—Review and editing, T.A.L., D.R.C.J., C.E.P., and T.E.L.J.

Funding: This research was funded by The Nature Conservancy of Texas on the project "Ecology and Management of Bat Communities using Cave Features on Ft. Hood Military Base.".

Acknowledgments: TAL thanks Janice Crenshaw and Ben Wu at Texas A\&M for support and guidance. We thank Paul Cavanaugh and The Nature Conservancy-Texas-based at Ft. Hood, Texas, for their funding and logistical support during the project.

Conflicts of Interest: The authors declare no conflict of interest.

\section{References}

1. Costanza, R.; d'Arge, R.; de Groot, R.; Farber, S.; Grasso, M.; Hannon, B.; Limburg, K.; Naeem, S.; O’Neill, R.V.; Paruelo, J.; et al. The value of the world's ecosystem services and natural capital. Nature 1997, 387, $253-260$. [CrossRef]

2. Hooper, D.U.; Chapin, F.S., III; Ewel, J.J.; Hector, A.; Inchausti, P.; Lavorel, S.; Lawton, J.H.; Lodge, D.M.; Loreau, M.; Naeem, S.; et al. Effects of biodiversity on ecosystem functioning: A consensus of current knowledge. Ecol. Monog. 2005, 75, 3-35. [CrossRef]

3. Lacher, T.E., Jr.; Davidson, A.; Fleming, T.; Gomez-Ruiz, E.P.; McCracken, G.; Owen-Smith, N.; Peres, C.; Vander Wall, S. The functional role of mammals in ecosystems. J. Mamm. 2019, 100, 942-964. [CrossRef]

4. Kunz, T.H.; de Torrez, E.B.; Bauer, D.; Lobova, T.; Fleming, T.H. Ecosystem services provided by bats. Ann. N. Y. Acad. Sci. 2011, 1223, 1-38. [CrossRef] [PubMed]

5. Jones, G.; Jacobs, D.S.; Kunz, T.H.; Willig, M.R.; Racey, P.A. Carpe noctem: The importance of bats as bioindicators. Endanger. Sp. Res. 2009, 8, 93-115. [CrossRef] 
6. Cleveland, C.J.; Betke, M.; Federico, P.; Frank, J.D.; Hallam, T.G.; Horn, J.; López, J.D., Jr.; McCracken, G.F.; Medellín, R.A.; Moreno-Valdez, A.; et al. Economic value of the pest control service provided by Brazilian free-tailed bats in south-central Texas. Front. Ecol. Environ. 2006, 4, 238-243. [CrossRef]

7. Willig, M.R. A bat monitoring network for global change in the Anthropocene: Now or never. In Proceedings of the International Symposium on the Importance of Bats as Bioindicators; Flaquer, C., Puig-Montserrat, X., Eds.; Museum of Natural Sciences Edicions: Granollers, Catalonia, Spain, 2012; pp. 20-25.

8. Hill, E.F. Organophosphorus and carbamate pesticides. In Handbook of Ecotoxicology; Hoffman, D.J., Rattner, B.A., Burton, G.A., Jr., Cairns, J., Jr., Eds.; Lewis Publishers: Boca Raton, FL, USA, 1995; pp. $243-273$.

9. Smith, G.J. Pesticide Use and Toxicology in Relation to Wildife: Organophosphorus and Carbamate Compounds; Resource Publication, 170; U.S. Fish and Wildlife Service: Washington, DC, USA, 1987.

10. Grue, C.E.; Hart, A.D.M.; Mineau, P. Biological consequences of depressed brain cholinesterase in wildlife. In Cholinesterase-Inhibiting Insecticides: Their Impact on Wildlife and the Environment; Mineau, P., Ed.; Elsevier Science Publishers: Amsterdam, The Netherlands, 1991; pp. 151-209.

11. Eto, M. Organophosphorus Pesticides: Organic and Biological Chemistry; CRC Press: Cleveland, OH, USA, 1974.

12. Kuhr, R.J.; Dorough, H.W. Carbamate Insecticides: Chemistry, Biochemistry, and Toxicology; CRC Press: Cleveland, OH, USA, 1976.

13. Grue, C.E.; Fleming, W.J.; Busby, D.G.; Hill, E.F. Assessing hazards of organophosphate pesticides to wildlife. T. N. Am. Wildl. Nat. Res. 1983, 48, 200-220.

14. Stromborg, K.L.; Grue, C.E.; Nichols, J.D.; Hepp, G.H.; Hines, J.E.; Bourne, H.C. Postfledgling survival of European starlings exposed to an organophosphorus insecticide. Ecology 1988, 50, 590-595. [CrossRef]

15. Peterle, T.J. Wildlife Toxicology; Van Nostrand Reinhold: New York, NY, USA, 1991.

16. Smith, A.G. Chlorinated hydrocarbon insecticides. In Handbook of Pesticide Toxicology; Hayes, W.J., Laws, E.R., Jr., Eds.; Academic Press: San Diego, CA, USA, 1991; pp. 816-850.

17. Clark, D.R., Jr.; Bunck, C.M.; Cromartie, E.; LaVal, R.K. Year and age effects on residues of dieldrin and heptachlor in dead gray bats, Franklin County, Missouri-1976,1977, and 1978. Environ. Toxicol. Chem. 1983, 2, 387-391.

18. Clark, D.R., Jr.; Clawson, R.L.; Stafford, C.J. Gray bats killed by dieldrin at two additional Missouri caves: Aquatic macroinvertebrates found dead. B. Environ. Contam. Tox. 1983, 30, 214-218. [CrossRef]

19. Ammerman, L.K.; Hice, C.L.; Schmidly, D.J. Bats of Texas; Texas A\&M University Press: College Station, TX, USA, 2012.

20. Fitch, J.H.; Shump, K.A., Jr.; Shump, A.U. Myotis velifer. Mamm. Species 1981, 149, 1-5. [CrossRef]

21. Shump, K.A. Cave myotis (Myotis velifer). In The Smithsonian Book of North American Mammals; Wilson, D.E., Ruff, S., Eds.; Smithsonian Institution Press: Washington, DC, USA, 1999; pp. 100-101.

22. Warton, M. Status of work on cave mapping and gating on Fort Hood Military Reservation. In The Nature Conservancy Summary of 1997 Research Activities; Texas Data Center, The Nature Conservancy: Fort Hood, TX, USA, 1997; pp. 229-256.

23. Reddell, J.R. Summary of past work on the cave biology of Ft. Hood, Bell and Coryell Counties, Texas. In The Nature Conservancy Summary of 1997 Research Activities; Texas Data Center, The Nature Conservancy: Fort Hood, TX, USA, 1997; pp. 257-314.

24. Land, T.A. Population Size and Contaminant Exposure of Bats Using Caves on Fort Hood Military Base. Master's Thesis, Texas A\&M University, College Station, TX, USA, 2001.

25. Land, T.A.; Lacher, T.E., Jr.; Clark, D.R., Jr. Emergence patterns of cave Myotis (Myotis velifer) on Fort Hood, in Central Texas. Bat. Res. News. 2003, 44, 92-94.

26. Sikes, R.S.; Gannon, W.L. Animal Care and Use Committee of the American Society of Mammalogists. Guidelines of the American Society of Mammalogists for the use of wild mammals in research. J. Mamm. 2011, 92, 235-253. [CrossRef]

27. Wade, T.L.; Atlas, E.L.; Brooks, J.M.; Kennicutt, M.C., II; Fox, R.G.; Sericano, J.L.; Garcia-Roero, B.; Defreitas, D.A. Gulf of Mexico status and trends program: Trace organic contaminant distribution in sediments and oysters. Estuaries 1988, 11, 1171-1179.

28. Sabala, A.; Portillo, J.L.; Broto-Puig, F.; Commellas, L. Development of a new high-performance liquid chromatography method to analyze $\mathrm{N}$-methylcarbamate insecticides by a simple post column derivatization system and fluorescence detection. J. Chromatogr. A 1997, 778, 103-110. [CrossRef] 
29. Pang, G.F.; Can, Y.Z.; Fan, C.L.; Zhang, J.J.; Li, X.M.; Mu, J.; Wang, D.; Liu, S.M.; Song, W.B.; Li, H.P.; et al. Interlaboratory study of identification and quantitation of multiresidue pyrethroids in agricultural products by gas chromatography-mass spectrometry. J. Chromatogr. A 2000, 882, 231-238. [CrossRef]

30. Clark, D.R., Jr.; LaVal, R.K.; Tuttle, M.D. Estimating pesticide burdens of bats from guano analyses. B. Environ. Contam. Tox. 1982, 24, 214-220. [CrossRef]

31. Kannan, K.; Yun, S.H.; Rudd, R.J.; Behr, M. High concentrations of persistent organic pollutants including PCBs, DDT, PBDEs and PFOS in little brown bats with white-nose syndrome in New York, USA. Chemosphere 2010, 80, 613-618. [CrossRef]

32. United States Public Health Service. Toxicology Profile for Aldrin and Dieldrin; Agency for Toxic Substances and Disease Registry: Atlanta, GA, USA, 2002.

33. Clark, D.R., Jr. DDT and the decline of free-tailed bats (Tadarida brasiliensis) at Carlsbad Caverns, New Mexico. Arch. Environ. Con. Tox. 2001, 40, 537-543.

34. Clark, D.R., Jr.; Moreno-Valdez, A.; Mora, M.A. Organochlorine residues in bat guano from nine Mexican caves, 1991. Ecotoxicology 1995, 4, 258-265. [CrossRef]

35. O'Shea, T.J.; Clark, D.R., Jr. An overview of contaminants and bats, with special reference to insecticides and the Indiana bat. In The Indiana bat: Biology and Management of an Endangered Species; Kurta, A., Kennedy, J., Eds.; Bat Conservation International: Austin, TX, USA, 2002; pp. 237-253.

36. Mispagel, C.; Allinson, M.; Allinson, G.; Iseki, N.; Grant, C.; Morita, M. DDT and metabolites residues in the southern bent-wing bat (Miniopterus schreibersii bassanii) of south-eastern Australia. Chemosphere 2004, 55, 997-1003. [CrossRef] [PubMed]

37. Hoffman, D.J.; Rattner, B.A.; Burton, G., Jr.; Cairns, J., Jr. Introduction. In Handbook of Ecotoxicology; Lewis Publishers: Boca Raton, FL, USA, 1995; pp. 1-12.

38. Wolfe, M.F.; Kendall, R.J. Age-dependent toxicity of diazinon and terbufos in European starlings (Sturnus vulgaris) and red-winged blackbirds (Agelaius phoeniceus). Environ. Toxicol. Chem. 1998, 17, 1300-1312. [CrossRef]

39. Agosta, S.J. Habitat use, diet and roost selection by the Big Brown Bat (Eptesicus fuscus) in North America: A case for conserving an abundant species. Mamm. Rev. 2002, 32, 179-198. [CrossRef]

40. Sandel, J.K. Insecticides and Bridge-Roosting Colonies of Mexican Free-Tailed Bats (Tadarida brasiliensis) in Texas. Master's Thesis, Texas A\&M University, College Station, TX, USA, 1999.

41. Pain, D.J. Lead in the environment. In Handbook of Ecotoxicology; Hoffman, D.J., Rattner, B.A., Burton, G.A., Jr., Cairns, J., Jr., Eds.; Lewis Publishers: Boca Raton, FL, USA, 1995; pp. 356-430.

42. Clark, D.R., Jr.; Shore, R.F. Chiroptera. In Ecotoxicology of Wild Mammals; Shore, R.F., Rattner, B.A., Eds.; John Wiley \& Sons: New York, NY, USA, 2001; pp. 159-214.

43. Theis, M.L.; Theis, K.M. Organochlorine residues in bats from Eckert James River Cave, Texas. Bull. Environ. Contam. Toxicol. 1997, 58, 673-680. [CrossRef]

44. Desforges, J.-P.W.; Ross, P.S.; Loseto, L.L. Transplacental transfer of polychlorinated biphenyls and polybrominated diphenyl ethers in arctic beluga whales (Delphinapterus leucas). Environ. Toxicol. Chem. 2012, 31, 296-300. [CrossRef]

45. Eidels, R.R.; Sparks, D.W.; Whitaker, J.O., Jr.; Sprague, C.A. Sub-lethal effects of chlorpyriphos on big brown bats (Eptesicus fuscus). Arch. Environ. Contam. Toxicol. 2016, 71, 322-335. [CrossRef]

46. Stahlschmidt, P.; Brühl, C.A. Bats at risk? Bat activity and insecticide residue analysis of food items in an apple orchard. Environ. Toxicol. Chem. 2012, 31, 1556-1563. [CrossRef]

47. Bernard, E.; Aguiar, L.M.S.; Machado, R.B. Discovering the Brazilian bat fauna: A task for two centuries? Mamm. Rev. 2010, 41, 23-39. [CrossRef]

48. Oliveira, J.M.; Losano, N.F.; Condessa, S.S.; Pereira de Freitas, R.M.; Cardoso, S.A.; Freitas, M.B.; de Oliveira, L.L. Exposure to deltamethrin induces oxidative stress and decreases of energy reserve in tissues of the Neotropical fruit bat Artibeus lituratus. Ecotoxicol. Environ. Saf. 2018, 148, 684-692. [CrossRef]

49. De Lange, H.J.; Lahr, J.; Van der Pol, J.J.C.; Wessels, Y.; Faber, J.H. Ecological vulnerability in wildlife: An expert judgment and multicriteria analysis tool using ecological traits to assess relative impact of pollutants. Environ. Toxicol. Chem. 2009, 28, 2233-2240. [CrossRef]

50. Corso, A.E.; Woolley, J.B.; Lacher, T.E., Jr. Using digital photography and image analysis software to estimate the emergence of bats at Tou Santi Cave, Dominica, West Indies. Caribbean J. Sci. 2010, 46, 169-175. [CrossRef]

51. Vaughan, T.A. Functional morphology of three bats: Eumops, Myotis, Macrotus. Univ. Kansas Publ. Mus. Nat. Hist. 1959, 12, 1-153. 
52. Kunz, T.H. Population studies of the cave bat (Myotis velifer): Reproduction, growth and development. Occas. Pap. Univ. Kansas Mus. Nat. Hist. 1973, 15, 1-43. [CrossRef]

53. Kunz, T.H. Feeding ecology of a temperate insectivorous bat (Myotis velifer). Ecology 1974, 55, 693-711. [CrossRef]

54. Lacher, T.E., Jr.; Roach, N. The status of biodiversity in the Anthropocene: Trends, threats, and actions. In Volume 3 (Biodiversity), The Encyclopedia of the Anthropocene; Lacher, T.E., Jr., Pyare, P., Eds.; Elsevier: Oxford, UK, 2018; pp. 1-8.

55. Voigt, C.C.; Kingston, T. (Eds.) Bats in the Anthropocene: Conservation of Bats in a Changing World; Springer Open: Heidelberg, Germany, 2016.

56. Williams-Guillén, K.; Olimpi, E.; Maas, B.; Taylor, P.J.; Arlettaz, R. Bats in the anthropogenic matrix: Challenges and opportunities for the conservation of Chiroptera and their ecosystem services in agricultural landscapes. In Bats in the Anthropocene: Conservation of Bats in a Changing World; Voigt, C.C., Kingston, T., Eds.; Springer Open: Heidelberg, Germany, 2016; pp. 151-186.

57. Bayat, S.; Geiser, F.; Kristiansen, P.; Wilson, S.C. Organic contaminants in bats: Trends and new issues. Environ. Internat. 2014, 63, 40-52. [CrossRef] [PubMed]

(C) 2019 by the authors. Licensee MDPI, Basel, Switzerland. This article is an open access article distributed under the terms and conditions of the Creative Commons Attribution (CC BY) license (http://creativecommons.org/licenses/by/4.0/). 